\title{
ROZWAŻANIA NAD ZRÓWNANIEM POZYCJI PRAWNEJ KOŚCIOLÓW I INNYCH ZWIĄZKÓW WYZNANIOWYCH ORAZ NIERELIGIJNYCH ORGANIZACJI ŚWIATOPOGLĄDOWYCH
}

\begin{abstract}
Streszczenie. Niniejszy artykuł stanowi próbę odpowiedzi na pytanie o istnienie przesłanek przemawiających za obligatoryjnym zrównaniem pozycji prawnej kościołów i innych związków wyznaniowych oraz niereligijnych organizacji światopoglądowych. W tym celu przeanalizowany zostanie status prawny badanych podmiotów w prawie polskim, stosunek Unii Europejskiej do rozbieżności występujących $\mathrm{w}$ tym zakresie oraz funkcje, jakie badane podmioty wypełniają wobec swych członków. Kontekst dla rozważań stanowią projekty ustaw powstałe w latach 2013-2019 dotyczące zastąpienia Funduszu Kościelnego obywatelskim odpisem podatkowym na rzecz kościołów i innych związków wyznaniowych oraz przyznania niereligijnym organizacjom światopoglądowym prawa do stałego, instytucjonalnego dialogu z państwem.
\end{abstract}

Słowa kluczowe: równouprawnienie, kościoły, związki wyznaniowe, niereligijne organizacje światopoglądowe.

W drugiej dekadzie XXI wieku pojawiły się w Polsce inicjatywy zmierzające do przyznania niereligijnym organizacjom światopoglądowym ${ }^{1}$ uprawnień, które zbliżyłyby status tych organizacji do statusu, jaki w prawie polskim posiadają kościoły i inne związki wyznaniowe. Próby takie miały miejsce zarówno w czasie VII, jak i VIII kadencji Sejmu Rzeczypospolitej Polskiej. W 2013 roku koalicyjny rząd Platformy Obywatelskiej i Polskiego Stronnictwa Ludowego przygotowywał reformę polegającą na zastąpieniu Funduszu Kościelnego obywatelskim odpisem podatkowym na rzecz kościołów i innych związków wyznaniowych. Jak wskazano w uzasadnieniu, celem projektowanych zmian było „doprowadzenie do usamodzielnienia kościołów i innych związków wyznaniowych w płaceniu składek na ubezpieczenie - emerytalne, rentowe, wypadkowe i zdrowotne, jako jednego z elementów prac zmierzających do kompleksowej reformy systemu emerytalnego" (Ministerstwo Cyfryzacji 2013, 11). W doktrynie podnoszono wówczas, że koniecznym jest, aby w krąg beneficjentów odpi-

*Uniwersytet Łódzki, lukasz.bernacinski@unilodz.eu.

${ }^{1} \mathrm{~W}$ niniejszym artykule pod pojęciem niereligijnych organizacji światopoglądowych autor rozumie stowarzyszenia lub fundacje, których celem jest krzewienie kultury świeckiej oraz zasad agnostycyzmu i ateizmu. 
su włączyć także niereligijne organizacje światopoglądowe. Nieuwzględnienie tych organizacji miało narażać państwo na zarzut preferowania światopoglądu religijnego, co stanowiłoby naruszenie zasady równości oraz zasady bezstronności światopoglądowej władz publicznych. Pominięcie organizacji światopoglądowych, które nie stawiają sobie celów religijnych lub których cele mają charakter antyreligijny, miało zostać odebrane także jako dyskryminacja osób niewierzących (Zieliński 2017, 106-107). W 2014 roku grupa posłów Twojego Ruchu przedstawiła projekt ustawy, który przyznawał organizacjom światopoglądowym prawo do stałego, instytucjonalnego dialogu z państwem (Twój Ruch 2014). Jak wskazano w uzasadnieniu, celem projektowanej zmiany było ,umożliwienie ustanowienia stałej instytucjonalnej platformy ułatwiającej relacje państwa oraz organizacji światopoglądowych". Ostatnią chronologicznie propozycją był przygotowany przez Inicjatywę Polską projekt ustawy o świeckim państwie (p.u.ś.p.), który wprowadzał obowiązek współpracy państwa z „reprezentatywnymi organizacjami świeckimi mającymi za cel krzewienie kultury świeckiej oraz zasad agnostycyzmu i ateizmu" na równi z kościołami i innymi związkami wyznaniowymi (Inicjatywa Polska 2019). W tym celu stworzona miała zostać Komisja Wspólna Rządu i Kościołów, Związków Wyznaniowych oraz Organizacji Świeckich².

Osiągnięciu celu w postaci udzielenia odpowiedzi na pytanie o zasadność zrównania uprawnień niereligijnych organizacji światopoglądowych oraz kościołów i innych związków wyznaniowych oraz o ewentualną niezgodność z Konstytucją Rzeczypospolitej Polskiej z dnia 2 kwietnia 1997 r. (Dz.U. Nr 78, poz. 483, Konstytucja) zróżnicowania statusu tych podmiotów, posłuży porównanie ich aktualnego statusu prawnego, a także funkcji jakie spełniają one wobec swych członków. W realizacji zadania wykorzystana zostanie przede wszystkim metoda formalno-dogmatyczna urzeczywistniająca się w analizie i interpretacji przepisów Konstytucji, aktów prawa międzynarodowego oraz ustaw zwykłych.

${ }^{2}$ Zaproponowane w p.u.ś.p. nowe brzmienie art. 16 Ustawy z dnia 17 maja 1989 r. o gwarancjach wolności sumienia i wyznania (tekst jednolity Dz.U. z 2017 r., poz. 1153, u.g.w.s.w.):

1. Państwo współdziała z kościołami, innymi związkami wyznaniowymi oraz reprezentatywnymi organizacjami świeckimi mającymi za cel krzewienie kultury świeckiej oraz zasad agnostycyzmu i ateizmu, w celu realizacji postanowień ustawy, a w szczególności gwarancji zasad wolności sumienia i wyznania.

2. W celu, o którym mowa w ust. 1, tworzy się Komisję Wspólną Rządu i Kościołów, Związków Wyznaniowych oraz Organizacji Świeckich.

3. Prezes Rady Ministrów określi w drodze Rozporządzenia skład Komisji oraz szczegółowe zasady jej działania, przy czym za reprezentatywne organizacje świeckie uznaje się te organizacje, które działają jako stowarzyszenie i zrzeszają co najmniej 1000 członkiń i członków w skali kraju albo działają jako fundacja od co najmniej 5 lat. 


\section{PORÓWNANIE POZYCJI PRAWNEJ KOŚCIOLÓW I INNYCH ZWIĄZKÓW WYZNANIOWYCH ORAZ NIERELIGIJNYCH ORGANIZACJI ŚWIATOPOGLĄDOWYCH}

Artykuł 1 u.g.w.s.w. stanowi o tym, że Rzeczpospolita Polska zapewnia każdemu obywatelowi wolność wyboru religii lub przekonań, a także wyrażania ich indywidualnie i zbiorowo, prywatnie i publicznie. W ust. 3 tegoż artykułu gwarantuje się równe prawa w życiu państwowym, politycznym, gospodarczym, społecznym i kulturalnym obywatelom wierzącym wszystkich wyznań oraz niewierzącym. Art. 7 tejże ustawy stanowi, że cudzoziemcy i bezpaństwowcy przebywający na terytorium Rzeczypospolitej Polskiej korzystają z wolności sumienia i wyznania na równi z obywatelami polskimi. Uregulowanie to jest w pełni koherentne z art. 53 ust. 1 Konstytucji. Jednostki, które korzystają z przyznanej wolności sumienia i wyznania, mogą między innymi zrzeszać się w organizacjach świeckich w celu realizacji zadań wynikających z wyznawanej religii bądź przekonań w sprawach religii (art. 2 pkt 11 u.g.w.s.w.). Należy jednak zauważyć, że kościoły i inne związki wyznaniowe oraz niereligijne organizacje światopoglądowe na gruncie prawa polskiego mają wyraźnie odmienny status prawny. Stosunek państwa do kościołów i innych związków konfesyjnych stał się przedmiotem regulacji już w pierwszym rozdziale Konstytucji, w którym znajdują się normy o charakterze ustrojowym. Oznacza to, że w III Rzeczypospolitej utrzymanie poprawnych stosunków państwa ze wspólnotami religijnymi urasta do rangi ustrojowej. Ponadto, kościoły i inne związki wyznaniowe stały się jedynym wymienionym expressis verbis w Konstytucji partnerem państwa we współdziałaniu dla dobra człowieka i dobra wspólnego ${ }^{3}$.

Ustawa zasadnicza przyznaje także poszczególnym wspólnotom wyznaniowym prawo do uregulowania swych relacji z państwem w odrębnej ustawie. W wypadku mniejszościowych związków konfesyjnych wymagane jest zawarcie umowy między Radą Ministrów a właściwymi przedstawicielami zainteresowanych związków, która poprzedza uchwalenie ustawy. W doktrynie przeważa stanowisko, zgodnie z którym obie strony dobrowolnie uczestniczą w procedurze zawarcia umowy (Uruszczak 2009, 482; Walencik 2010, 44; Olszówka 2010, 31-45), choć Trybunał Konstytucyjny uznał, że kościoły i inne związki wyznaniowe mają prawo żądać przygotowania przez rząd projektów aktów normatywnych i uchwalenia ustaw przez Sejm RP, jeśli posiadają cechę relewantną wspólną ze związkiem wyznaniowym o pozycji prawnej uregulowanej w ustawie indywidualnej (wyrok TK z 14 grudnia 2009 r., K 55/07 OTK ZU 2009, seria A, nr 11, poz. 167, pkt III.7; podobnie: Pietrzak

${ }^{3}$ Zasada wyrażona w art. 25 ust. 3 Konstytucji ma charakter normy programowej, dlatego też nie rodzi roszczeń instytucji wyznaniowych względem państwa (Zob. szerzej: Gizbert-Studnicki, Grabowski 1997). 
1997, 180). Umowa zawierana przez Radę Ministrów z właściwymi przedstawicielami kościołów i innych związków wyznaniowych przesądza o treści przyszłej ustawy i pozostaje z nią w ścisłej zależności (Witkowski 2000, 104; Walencik 2011, 101). W doktrynie wskazuje się nawet na tożsamość substancjalną, merytoryczną ustawy i umowy (Zieliński 2003, 53). Wskazuje się także, że najlepszym zabezpieczeniem trwałości wypracowywanych rozwiązań jest wprowadzenie do umowy, w formie załącznika, gotowego projektu ustawy objętego porozumieniem stron (Borecki 2012, 139-140). Umowa taka nie jest źródłem prawa, lecz jawi się jako instytucjonalny wyraz realizacji przyznanej związkom wyznaniowym częściowej kompetencji normodawczej (Olszówka 2013, 307). Zgodnie z Konstytucją, uchwalenie ustawy dotyczącej stosunków państwa z Kościołem katolickim nie wymaga zawarcia wcześniejszej umowy (art. 25 ust. 4). Inaczej orzekł Trybunał Konstytucyjny (wyr. TK z 2.04.2003 r., K 13/02, OTK-A 2003, nr 4, poz. 28 z glosą krytyczną: Borecki, Pietrzak 2003, 100-101). Z faktu, iż ustrojodawca nadał zróżnicowaną treść art. 25 ust. 4 i 5 , można wyprowadzić wniosek, że jego działanie ma znaczenie prawne. Ponadto zawarcie uprzedniej umowy, której postanowienia są tożsame z uchwalaną później ustawą, stanowi istotne ograniczenie suwerenności ustawodawczej parlamentu (Sobczyk 2013, 344 i n.). Kościół katolicki, z uwagi na fakt, że Stolica Apostolska jest suwerennym podmiotem prawa międzynarodowego, może kształtować swe stosunki z państwem także w formie umowy międzynarodowej (konkordatu). Ustawodawstwo krajowe nie może być sprzeczne $\mathrm{z}$ umową ratyfikowaną za zgodą Sejmu RP wyrażoną w ustawie, czyli także z konkordatem ${ }^{4}$. Zgodnie z art. 27 Konkordatu między Stolicą Apostolską i Rzecząpospolitą Polską, podpisanego w Warszawie dnia 28 lipca 1993 r. (Dz.U. z 1998 r. Nr 51, poz. 318, Konkordat) uchwalenie konkretnej ustawy powinno zostać poprzedzone zawarciem porozumienia między stroną państwową i kościelną w formie umowy lub uzgodnień. Przepis ten stanowi proceduralną gwarancję układowej formy regulacji stosunków państwa z Kościołem katolickim, stąd też spełnia w praktyce tę samą funkcję, co art. 25 ust. 5 Konstytucji w odniesieniu do mniejszościowych wspólnot religijnych (Walencik 2011, 104). W praktyce zatem regulacja stosunków państwa z Kościołem katolickim bez wcześniejszego porozumienia w formie uzgodnień lub umowy nie jest możliwa.

Ustrojodawca w art. 25 ust. 4-5 Konstytucji przewidział zróżnicowane formy prawne regulacji stosunków państwa z kościołami i innymi związkami wyznaniowymi - konkordatowo-ustawową dla Kościoła katolickiego oraz umowno-ustawową w wypadku pozostałych kościołów i innych związków konfesyjnych. W rzeczywistości wyróżnić można także trzecią formę regulacji, czyli rejestrację związków wyznaniowych na podstawie przepisów działu III u.g.w.s.w.

${ }^{4}$ Zob. Art. 91 ust. 2 Konstytucji; Ustawa z dnia 8 stycznia 1998 r. o ratyfikacji Konkordatu między Stolicą Apostolską a Rzecząpospolitą Polską (Dz.U. Nr 12, poz. 42). 
(art. 30-38). Efektem tak ukształtowanych form regulacji jest stosowany w praktyce podział na związki wyznaniowe uznane na podstawie odrębnych (indywidualnych) ustaw oraz te zalegalizowane w trybie rejestracyjnym (Krukowski 2008, 81-83). Prawo wpisu do rejestru kościołów i innych związków wyznaniowych jest realizowane przez złożenie ministrowi prowadzącemu rejestr (obecnie jest to Minister Spraw Wewnętrznych i Administracji) deklaracji o utworzeniu kościoła lub innego związku wyznaniowego i wniosku o wpis do rejestru. Prawo wniesienia wniosku przysługuje co najmniej 100 obywatelom polskim posiadającym pełną zdolność do czynności prawnych (art. 30-31 u.g.w.s.w.) Z chwilą wpisu do rejestru kościół lub inny związek wyznaniowy uzyskuje, jako całość, osobowość prawną oraz korzysta ze wszystkich uprawnień i podlega obowiązkom określonym w ustawach (art. 34 ust.2 u.g.w.s.w.). Zarejestrowane kościoły i inne związki wyznaniowe mogą wystąpić do ministra właściwego do spraw wewnętrznych z wnioskiem o zawarcie umowy, która będzie stanowiła podstawę do uchwalenia ustawy indywidualnej (por. art. 40 u.g.w.s.w.).

Konstytucja w art. 58 stanowi, że każdemu zapewnia się wolność zrzeszania się, zaś zakazane są zrzeszenia, których cel lub działalność są sprzeczne z Konstytucją lub ustawą ${ }^{5}$. Niereligijne organizacje światopoglądowe działają na zasadach ogólnych właściwych dla stowarzyszeń lub fundacji. Organizacje te nie cieszą się w Polsce statusem prawnym zbliżonym do tego, jaki mają kościoły i inne związki wyznaniowe. W szczególności ochrona praw niereligijnych organizacji światopoglądowych nie jest gwarantowana poprzez obowiązek zawarcia uprzedniej względem uchwalenia ustawy umowy między Radą Ministrów a przedstawicielami zainteresowanych organizacji. Nie istnieje także konstytucyjny obowiązek współdziałania państwa z niereligijnymi organizacjami światopoglądowymi dla dobra człowieka i dobra wspólnego - co nie zmienia faktu, że taka współpraca jest możliwa. Co więcej, w VII kadencji Sejmu RP zasiadający w niższej izbie parlamentu przedstawiciele Narodu, do którego należy zwierzchnia władza w Rzeczypospolitej Polskiej (por. art. 4 Konstytucji), nie wyrazili aprobaty dla zrównana statusu niereligijnych organizacji światopoglądowych oraz wspólnot religijnych, nawet w niektórych jedynie aspektach. Świadczy o tym fakt, że przedstawiony wówczas przez grupę posłów Twojego Ruchu projekt ustawy, który miał na celu przyznanie niereligijnym organizacjom światopoglądowym prawa do stałego, instytucjonalnego dialogu z państwem, został zaopiniowany negatywnie przez Komisję Administracji i Cyfryzacji (Komisja Administracji i Cyfryzacji 2014), zaś wniosek o odrzucenie projektu ustawy w pierwszym czytaniu pozostał bez rozpatrzenia do końca kadencji (Sejm 2015).

${ }^{5}$ Przepis ten odczytywany łącznie z konstytucyjną zasadą wolności sumienia i religii (art. 53 ust. 1) oraz ustawową gwarancją wolności sumienia i wyznania (art. 1 ust. 1-2 i art. 2 pkt 1) stanowi także podstawę dla tworzenia wspólnot religijnych. 


\section{STOSUNEK UNII EUROPEJSKIEJ DO STATUSU PRAWNEGO KOŚCIOŁÓW I INNYCH ZWIĄZKÓW WYZNANIOWYCH ORAZ NIERELIGIJNYCH ORGANIZACJI ŚWIATOPOGLĄDOWYCH W PRAWIE WEWNĘTRZNYM PAŃSTW CZLONKOWSKICH}

Pierwszą polityczną deklaracją w kwestii stosunku Unii Europejskiej do statusu wspólnot wyznaniowych i niereligijnych organizacji światopoglądowych w prawie wewnętrznym państw członkowskich była Deklaracja $11 \mathrm{w}$ sprawie statusu kościołów i organizacji niewyznaniowych dołączona do Traktatu z Amsterdamu (Traktat amsterdamski; Dz. Urz. UE C 340 z 10 października 1997). Stanowiła ona, że Unia Europejska szanuje i nie narusza statusu, z którego korzystają, na mocy prawa krajowego, kościoły, stowarzyszenia lub wspólnoty religijne, a także organizacje filozoficzne i niewyznaniowe w Państwach Członkowskich. Tekst deklaracji można uznać za kompromisowy, bowiem Republika Federalna Niemiec, w której modelem stosunków państwo-kościół jest separacja skoordynowana, a najważniejsze wspólnoty wyznaniowe mają status korporacji prawa publicznego, postulowała uzupełnienie treści Traktatu amsterdamskiego o zapis podkreślający rolę wspólnot wyznaniowych w budowaniu tożsamości państw członkowskich oraz wspólnego dziedzictwa kulturowego Europy: „Unia przestrzega konstytucyjno-prawnej pozycji wspólnot wyznaniowych w państwach członkowskich jako wyrazu tożsamości państw członkowskich i ich kultur oraz jako część wspólnego dziedzictwa kulturowego". Do wprowadzenia takiego zapisu do Traktatu amsterdamskiego konieczna była jednomyślność, zaś tej nie udało się osiągnąć ze względu na sprzeciw części państw członkowskich pod przewodnictwem Francji, w której obowiązuje model separacji wrogiej kościoła i państwa (Krukowski 2008, 278-279; Przyborowska-Klimczak 2000, 46-50). Unia Europejska zadeklarowała, że nie będzie ingerować w wynikający z przepisów prawa krajowego status wspólnot wyznaniowych i niereligijnych organizacji światopoglądowych, zaś jej organy będą ten status respektować, nie naruszając go. W projekcie Traktatu ustanawiającego Konstytucję dla Europy powtórzono tekst Deklaracji 11, dodając jednak novum w postaci zasady poszanowania tożsamości i wkładu wspólnot religijnych i organizacji światopoglądowych oraz dialogu z tymi podmiotami: „Uznając tożsamość i szczególny wkład tych kościołów i organizacji światopoglądowych Unia utrzymuje z nimi otwarty, przejrzysty i regularny dialog" (Art. I-52 Traktatu ustanawiającego Konstytucję dla Europy, Dz. Urz. UE C 310 z 16 grudnia 2004 r., wyd. pol., zawiad. nr 2004/C 310/01). Brak ratyfikacji traktatu przez wszystkie strony przesądził o tym, że nie wszedł on w życie. Aktualną podstawą prawną dla oceny stosunku Unii Europejskiej do statusu prawnego wspólnot wyznaniowych i niereligijnych organizacji światopoglądowych jest art. 17 Traktatu o funkcjonowaniu Unii Europejskiej (Dz. Urz. UE C 306 z 17 grudnia 2007 r., TFUE), który stanowi: „1. Unia szanuje status przyznany na mocy prawa krajowego kościołom 
i stowarzyszeniom lub wspólnotom religijnym w Państwach Członkowskich i nie narusza tego statusu. 2. Unia szanuje również status organizacji światopoglądowych i niewyznaniowych przyznany im na mocy prawa krajowego. 3. Uznając tożsamość i szczególny wkład tych kościołów i organizacji, Unia prowadzi z nimi otwarty, przejrzysty i regularny dialog."

Trzeba także wskazać, że Unia Europejska nie ma kompetencji do stanowienia prawa bezpośrednio dotyczącego zjawiska religijności. Wynika to z zasady przyznania, zgodnie z którą Unia Europejska działa wyłącznie w granicach kompetencji przyznanych jej przez państwa członkowskie w traktatach do osiągnięcia określonych w nich celów, zaś wszelkie kompetencje nieprzyznane Unii w traktatach należą do państw członkowskich (art. 5 ust. 1-2 Traktatu o Unii Europejskiej, Dz. Urz. UE C 191 z 29 lipca 1992 r.). Regulacja stosunków państwa z kościołami i innymi związkami wyznaniowymi nie mieści się w żadnej z kategorii kompetencji przyznanych Unii Europejskiej (por. w szczególności art. 2-6 TFUE). Powołany wyżej art. 17 TFUE potwierdza zasadę nieingerencji Unii Europejskiej w status kościołów i innych związków wyznaniowych (ust. 1) oraz organizacji świeckich i niewyznaniowych (ust. 2) w prawie wewnętrznym państw członkowskich. Należy zatem stwierdzić, że państwa członkowskie mają wyłączną kompetencję do określania modelu państwa z uwagi na jego stosunek do zjawiska religijności (Mezglewski, Misztal, Stanisz 2011, 42).

Podsumowując tę część rozważań trzeba stwierdzić, że organy Unii Europejskiej nie ingerują w status kościołów i innych związków wyznaniowych oraz niereligijnych organizacji światopoglądowych, przyznany im w prawie krajowym państw członkowskich. W szczególności niedopuszczalna jest unifikacja tegoż statusu na terenie wspólnoty. Prawo Unii Europejskiej respektuje różnorodne systemy relacji państwa ze wspólnotami wyznaniowymi oraz niereligijnymi organizacjami światopoglądowymi, które funkcjonują w państwach członkowskich. Józef Krukowski podkreśla, że Traktat o funkcjonowaniu Unii Europejskiej stanowi gwarancję poszanowania przez organy Unii Europejskiej statusu kościołów i innych związków wyznaniowych w prawie krajowym państw członkowskich, zaś w wypadku kolizji norm prawa Unii Europejskiej i państwa członkowskiego pierwszeństwo należy przyznać normie prawa krajowego. Ponadto sformułowanie art. 17 przedmiotowego traktatu wyklucza możliwość narzucenia przez organy Unii Europejskiej państwom członkowskim określonego modelu relacji państwo-kościół (Krukowski 2008, 282). W związku z powyższym w prawie Unii Europejskiej nie ma przepisu, który przesądzałby o konieczności zrównania statusu prawnego kościołów i innych związków wyznaniowych oraz niereligijnych organizacji światopoglądowych (odmiennie: Pietrzak 2013, 312). 


\section{PORÓWNANIE FUNKCJI, JAKIE WOBEC SWYCH CZLONKÓW WYPEŁNIAJĄ KOŚCIOLY I INNE ZWIĄZKI WYZNANIOWE ORAZ NIERELIGIJNE ORGANIZACJE ŚWIATOPOGLĄDOWE}

Badając podobieństwo kościołów i innych związków wyznaniowych oraz niereligijnych organizacji światopoglądowych nie można poprzestawać na analizie statusu prawnego, jaki podmiotom tym aktualnie się przyznaje. Wynika to $\mathrm{z}$ faktu, że ustawodawca mógłby arbitralnie umniejszać znaczenie niereligijnych organizacji światopoglądowych, faworyzując równocześnie wspólnoty wyznaniowe, co doprowadziłoby do nieuzasadnionego różnicowania ich statusu prawnego. Wobec powyższego zbadać należy pozaprawne podobieństwa, a wśród nich na pierwszym miejscu funkcje, jakie porównywane podmioty wypełniają wobec swych członków.

Już na początku trzeba zauważyć, że powstanie i funkcjonowanie niereligijnych organizacji światopoglądowych zakotwiczone jest w negacji zadań, których wypełnianie jest istotą działalności kościołów i innych związków konfesyjnych. Związki wyznaniowe istnieją w celu wyznawania i szerzenia wiary religijnej (por. art. 2 pkt 1 u.g.w.s.w.) oraz zaspokajania potrzeb duchowych swych członków. Zadania realizowane przez niereligijne organizacje światopoglądowe to między innymi promocja tolerancji i szacunku wobec mniejszości, popularyzacja nauki, udzielanie pomocy osobom dyskryminowanym lub poddawanym ostracyzmowi, wspieranie szkół i nauczycieli w organizacji i prowadzeniu lekcji etyki, pełnienie roli organizacji strażniczych wobec władz pod kątem wpływu przesądów na stanowienie, wykonywanie i egzekwowanie prawa, ostrzeganie przed grupami psychomanipulacyjnymi czy promocja krytycznego myślenia (Racjonalista 2012). Jak dalej wskazuje Polskie Stowarzyszenie Racjonalistów, nie ma powodu, by niereligijne organizacje światopoglądowe były dyskryminowane tylko $\mathrm{z}$ tego powodu, że „ich działalność nie jest związana z mitologią”, a równe prawa powinny przysługiwać wszystkim jednostkom, „niezależnie od tego, czy ich światopogląd uwzględnia istnienie istot magicznych, a zatem może być reprezentowany przez organizację o statusie związku wyznaniowego". Powyższe potwierdza, że niereligijne organizacje światopoglądowe stawiają sobie za cel krzewienie kultury świeckiej (niezależnej od doświadczania i przeżywania religijności) oraz zasad agnostycyzmu i ateizmu (por. art. 1 p.u.ś.p.), czyli światopoglądu zaprzeczającemu istnieniu Boga, bądź negującego możliwość jego poznania. Cele te są biegunowo różne od zadań, jakie realizują kościoły i inne związki wyznaniowe, czyli zbliżaniu ludzi do Boga (przynajmniej pozornie) poprzez lepsze Jego poznanie i zrozumienie. Trzeba także zauważyć, że chociaż kościoły i inne związki wyznaniowe oraz niereligijne organizacje światopoglądowe podejmują przynajmniej część swych działań w tych samych obszarach życia społecznego (np. edukacja, nauka, promowanie określonych postaw społecznych uznanych przez te podmioty 
za właściwe), to cele, jakie sobie stawiają i projektowane efekty ich aktywności są częstokroć rozbieżne.

Niereligijne organizacje światopoglądowe opierając się na afirmacji światopoglądu niereligijnego czy antyreligijnego, hołdującego rozumowi, a także analizie wiary wyłącznie na podstawie poznania doświadczalnego, zaspokajają potrzeby rozumowo-poznawcze swych członków, a nie duchowe. Chociaż pojawiają się głosy opowiadające się za tezą, że organizacje świeckie zaspokajają także potrzeby duchowe swych członków, to nawet wówczas podkreśla się, że dokonuje się to tylko ,w pewnym stopniu analogicznie do potrzeb wyznawców wspólnot religijnych" (Zieliński 2017, 107). Trzeba przy tym zauważyć, że różnicowanie statusu prawnego na gruncie art. 32 (zasada równości) lub art. 25 ust. 1 (zasada równouprawnienia kościołów i innych związków wyznaniowych) Konstytucji jest możliwe między innymi wtedy, gdy porównywane podmioty nie wykazują cechy relewantnej w równym stopniu (Abramowicz 2015, 238-240). Za dopuszczalne przesłanki różnicowania, obok funkcji, jaką podmioty wypełniają wobec swych członków, uznać można także: zakorzenienie w dziejach państwa i narodu, specyficzną funkcję wspólnot religijnych w społeczeństwie, powszechność członkostwa czy zakres wykonywania funkcji publicznych.

Wyżej opisane różnice zauważył i potwierdził racjonalny ustrojodawca, który w art. 25 ust. 1 Konstytucji użył pojęć zastanych, którymi są „kościoły i inne związki wyznaniowe". Do ich zakresu podmiotowego zalicza się jedynie podmioty o sformalizowanej strukturze organizacyjnej, która ma na celu stworzenie możliwości zaspokajania potrzeb religijnych przez członków. Ponadto, ich doktryna musi przewidywać istnienie bytu nadrzędnego zwanego bogiem (wyr. NSA z 23.01.1998 r., I SA 1065/97, ONSA 1998, z. 4, poz. 135). Podobnie, w art. 2 pkt 1 u.g.w.s.w., ustawodawca wskazuje w odniesieniu do kościołów i innych związków wyznaniowych na cel ich działalności w postaci wyznawania i szerzenia wiary religijnej oraz cechy, którymi są: własny ustrój, doktryna i obrzędy kultowe. Ów cel i cechy są obce niereligijnym organizacjom światopoglądowym. Powyższe argumenty wskazują na świadomą decyzję suwerena o przyznaniu szczególnych uprawnień jedynie podmiotom posiadającym wyżej wymienione cechy oraz cel swego istnienia i działania.

\section{RÓŻNICOWANIE STATUSU KOŚCIOŁÓW I INNYCH ZWIĄZKÓW WYZNANIOWYCH ORAZ NIERELIGIJNYCH ORGANIZACJI ŚWIATOPOGLĄDOWYCH W ŚWIETLE ZASADY BEZSTRONNOŚCI ŚWIATOPOGLĄDOWEJ WLADZ PUBLICZNYCH}

$Z$ art. 25 ust. 2 Konstytucji stanowiącego o zasadzie bezstronności władz publicznych w sprawach przekonań religijnych, światopoglądowych i filozoficznych, wywodzi się, że państwo nie ma kompetencji do potwierdzenia, że określone 
przekonania religijne, światopoglądowe czy filozoficzne są jedynymi prawdziwymi. W tym kontekście mówi się o niekompetencji religijnej państwa, które nie ma uprawnień do oceniania w zakresie właściwości i słuszności doktryny, nauczania i praktyk religijnych (Zieliński 2009, 163-165). Państwo bezstronne światopoglądowo nie tylko nie ma kompetencji, ale nawet nie może zajmować stanowiska $\mathrm{w}$ kwestii prawdziwości poglądów głoszonych przez teologię poszczególnych wyznań czy przez poszczególne nurty filozoficzne. Jednocześnie państwo może zauważać i uznawać znaczenie dla człowieka teologii różnych wyznań oraz filozofii we wszystkich jej nurtach oraz wkład tych dziedzin wiedzy w rozwój kultury i myśli o człowieku (wyr. TK z 14.12.2009 r., K 55/07, OTK-A 2009, nr 11, poz. 167, pkt III.5). W związku z tym władze publiczne powstrzymują się od afirmacji wybranego światopoglądu, a także respektują zakaz dyskryminacji jednostek ze względu na wyznawane przez nie poglądy.

Zachowywanie bezstronności $\mathrm{w}$ prawie ${ }^{6}$ rozumianej jako uwzględnianie zasady bezstronności światopoglądowej władz publicznych w procesie kształtowania obowiązującego prawa nie może jednak oznaczać nihilizmu aksjologicznego. O przyjęciu jakichś podstaw aksjologicznych świadczy sformułowanie przepisów konstytucyjnych, a szczególnie zasad ustrojowych, ponieważ immanentną cechą norm prawnych jest ich aksjologiczny fundament, na którego kształtowanie się mają wpływ normy etyczne, moralne czy religijne funkcjonujące w społeczeństwie. Bezstronność światopoglądowa władz publicznych oparta jest na uniwersalnych wartościach etycznych wymienionych w preambule Konstytucji, ale także obecnych w dziedzictwie narodowym, które $\mathrm{w}$ istotnym stopniu ukształtowane zostało przez chrześcijaństwo. Polski system prawny respektuje także uniwersalne wartości etyczne, wyrosłe na bazie wartości chrześcijańskich i zakotwiczone w godności osoby ludzkiej, które zostały usankcjonowane w umowach międzynarodowych z zakresu praw człowieka (Krukowski 2008, 72-73).

Funkcjonowanie zarówno kościołów i innych związków wyznaniowych, jak również niereligijnych organizacji światopoglądowych, uzasadnia się gwarantowaną konstytucyjnie wolnością sumienia i religii, której źródłem jest godność osoby ludzkiej (art. 53 i art. 30 Konstytucji). Jednostka może w wolny sposób przyjąć światopogląd religijny albo niereligijny i szukać w odpowiednich instytucjach zaspokojenia związanych z tym wyborem potrzeb. Fakt, że funkcjonowanie wspólnot religijnych i niereligijnych organizacji światopoglądowych ma podstawę w tym samym prawie człowieka nie przesądza o tym, że bezstronny światopoglądowo ustawodawca nie może różnicować statusu prawnego tychże podmiotów. Zróżnicowanie jest dopuszczalne nie ze względu na przekonania światopoglądowe ustawodawcy, lecz z uwagi na spełnianie

${ }^{6} \mathrm{O}$ rozróżnieniu bezstronności prawa i bezstronności w prawie zob. szerzej: Brzozowski 2011, 57. 
przez podmioty, o których mowa, rozbieżnych funkcji, zaspokajanie innych potrzeb, różnokierunkową działalność społeczną, różny zakres realizacji zadań publicznych, rozbieżną formację intelektualną i aksjologiczną, liczebność czy powszechność członkostwa oraz stopień zakorzenienia w dziejach państwa i narodu. Powyższe, przykładowe cechy świadczą o zakresie i sile oddziaływania podmiotu oraz wartościach przekazywanych i przyjmowanych przez członków społeczeństwa. Powyższe elementy powodują diametralnie różne skutki dla funkcjonowania społeczeństwa i państwa oraz są obiektywnym kryterium różnicowania statusu prawnego kościołów i innych związków wyznaniowych oraz niereligijnych organizacji światopoglądowych.

Trzeba podkreślić, że bezstronność władz publicznych oznacza także, że zmiana istniejącego status quo w sferze wolności sumienia i wyznania jest dopuszczalna jedynie bez ingerencji państwa, w sposób naturalny, czyli w wyniku ewolucji struktury świadomości społecznej, przy istniejącej swobodzie przekonań religijnych czy światopoglądowych i swobodzie wyboru dokonywanego przez każdą jednostkę (Wyr. TK z 2.12.2009 r., U 10/07, OTK-A 2009, nr 11, poz. 163). Wynika z tego, że ustawodawstwo powinno podążać za strukturą światopoglądową społeczeństwa, a nie oddziaływać na tę strukturę w celu jej zmiany.

Ponadto ważnym kryterium badania zgodności przepisów różnicujących status prawny kościołów i innych związków wyznaniowych oraz niereligijnych organizacji światopoglądowych z zasadą bezstronności światopoglądowej władz publicznych jest cel ustawodawczy. Nie może być on motywowany uprzywilejowaniem określonej grupy podmiotów z pobudek religijnych czy światopoglądowych, lecz powinien wynikać z obiektywnych przesłanek. Powinien także być niesprzeczny z przekonaniami większości społeczeństwa oraz uwzględniać spodziewane (pozytywne) skutki społeczne. Dopuszczalne jest, aby ustawodawca osiągnął założone cele o charakterze świeckim, dzięki wykorzystaniu funkcjonowania wspólnot religijnych lub niereligijnych organizacji światopoglądowych, co ze względu na istniejące między nimi obiektywne $\mathrm{i}$ istotne odmienności nieuchronnie prowadzi do zróżnicowania statusu prawnego tychże podmiotów.

\section{PODSUMOWANIE}

W Polsce ugruntowany jest odmienny status prawny kościołów i innych związków wyznaniowych oraz niereligijnych organizacji światopoglądowych. Unia Europejska akceptuje zróżnicowaną pozycję prawną wspólnot wyznaniowych i organizacji światopoglądowych w państwach członkowskich, nie ingeruje w ich status prawny poprzez dążenie do jego zrównania. Także badanie funkcji i celu powstania organizacji świeckich przemawia za uznaniem daleko idących odmienności między nimi a wspólnotami religijnymi. Do podobnych 
wniosków prowadzą obiektywne przesłanki, odnoszące się do sytuacji faktycznej, w jakiej znajdują się porównywane podmioty i uzasadniające różnicowanie ich pozycji prawnej. Pewnym truizmem będzie przedstawienie w tym miejscu konstatacji, że zasada równouprawnienia kościołów i innych związków wyznaniowych (art. 25 ust. 1 Konstytucji) nakłada na władze publiczne obowiązek równego traktowania podmiotów należących do kategorii kościołów i innych związków wyznaniowych i nie dotyczy równouprawnienia podmiotów należących do innych kategorii. Także zasada bezstronności światopoglądowej władz publicznych nie wyklucza różnicowania statusu prawnego kościołów i innych związków wyznaniowych oraz niereligijnych organizacji światopoglądowych. W związku z powyższym trzeba stwierdzić, że w obecnym stanie prawnym nie istnieją przesłanki wymagające obligatoryjnego zrównania uprawnień wspólnot oraz niereligijnych organizacji światopoglądowych. Co więcej, praktyka parlamentarna wskazuje, że próby zrównania statusu prawnego obu grup podmiotów w niektórych jedynie kwestiach, napotykały w ostatnim dziesięcioleciu na jednoznaczny sprzeciw.

\section{BIBLIOGRAFIA}

Abramowicz, Aneta Maria. 2015. „Zasada równouprawnienia związków wyznaniowych w orzecznictwie Trybunału Konstytucyjnego". Studia z Prawa Wyznaniowego 18: 231-261.

Borecki, Paweł. 2012. „Dylematy likwidacji Funduszu Kościelnego i komisji regulacyjnych”. Przeglad Prawa Wyznaniowego 4: 125-144.

Borecki, Paweł. Michał Pietrzak. 2003. „Glosa do wyroku TK z dnia 2 kwietnia 2003 r., K 13/02”. Przeglad Sejmowy 5: 96-113.

Brzozowski, Wojciech. 2011. Bezstronność światopogladowa władz publicznych w Konstytucji RP. Warszawa: Wolters Kluwer Polska.

Gizbert-Studnicki, Tomasz. Andrzej Grabowski. 1997. „Normy programowe w konstytucji”. W Charakter i struktura norm konstytucji. 95-113. Red. Janusz Trzciński. Warszawa: Wydawnictwo Sejmowe.

Inicjatywa Polska. 2019. „Projekt ustawy o świeckim państwie”. http://inicjatywa25.pl/petycja.html [dostęp: 7.01.2020].

Komisja Administracji i Cyfryzacji. 2014. „Druk nr 2948. Sprawozdanie Komisji Administracji i Cyfryzacji o poselskim projekcie ustawy o zmianie ustawy o gwarancjach wolności sumienia i wyznania (druk nr 2482). http://orka.sejm.gov.pl/Druki7ka.nsf/0/41B7ACA7544F7825C125 7D9D004AE64A/\%24File/2948.pdf [dostęp: 15.03.2020].

Krukowski, Józef. 2008. Polskie prawo wyznaniowe. Warszawa: LexisNexis.

Mezglewski, Artur. Henryk Misztal. Piotr Stanisz. 2011. Prawo wyznaniowe. Warszawa: C.H. Beck.

Ministerstwo Cyfryzacji. 2013. „Projekt ustawy o zmianie ustawy o gwarancjach wolności sumienia i wyznania oraz niektórych innych ustaw". https://mc.bip.gov.pl/archiwum-bip-mac/prawoi-prace-legislacyjne-archiwum/projekty-aktow-prawnych-archiwum/projekt-ustawy-ozmianie-ustawy-o-gwarancjach-wolnosci-sumienia-i-wyznania.html [dostęp: 16.04.2020].

Olszówka, Marcin. 2010. „Zawieranie umów i uchwalanie ustaw, o których mowa w art. 25 ust. 5 Konstytucji RP”. Przegląd Sejmowy 6: 53-54. 
Olszówka, Marcin. 2013. „Charakter prawny umowy, o której mowa w art. 25 ust. 5 Konstytucji RP”. W Ukladowe formy regulacji stosunków między państwem a zwiazkami wyznaniowymi (art. 25 ust. 4-5 Konstytucji RP). 289-309. Red. Piotr Stanisz, Marta Ordon. Lublin: Wydawnictwo KUL.

Pietrzak, Michał. 1997. „Stosunki państwo-kościół w nowej Konstytucji”. Państwo i Prawo 11-12: 173-184.

Pietrzak, Michał. 2013. Prawo wyznaniowe, Warszawa: LexisNexis.

Przyborowska-Klimczak, Anna. 2000. „Klauzula o Kościołach w Traktacie Amsterdamskim z 1997 roku”. Prawo-Administracja-Kościół 2-3: 43-56.

Racjonalista. 2020. „Uwagi Polskiego Stowarzyszenia Racjonalistów do wyznaniowego odpisu podatkowego". http://www.racjonalista.pl/kk.php/s,7954 [dostęp: 18.04.2012].

Sejm. 2015. „Wykaz nierozpatrzonych przez Sejm sprawozdań o projektach ustaw (stan na 2.11.2015)". http://orka.sejm.gov.pl/proc7.nsf/0/12562E566E948344C1257988004BA5B D?Open [dostęp: 17.04.2020].

Sobczyk, Paweł. 2013. Konstytucyjna zasada konsensualnego określania stosunków między Rzeczapospolita Polska a Kościotem katolickim. Warszawa: Oficyna Wydawnicza ASPRA-JR.

Twój Ruch. 2014. „Druk nr 2482. Projekt ustawy o zmianie ustawy o gwarancjach wolności sumienia i wyznania". http://orka.sejm.gov.pl/Druki7ka.nsf/0/5391924C384BD110C1257CF 3004324E2/\%24File/2482.pdf [dostęp: 15.03.2020].

Uruszczak, Wacław. 2009. „Art. 25 ust. 5 Konstytucji Rzeczypospolitej Polskiej. Problemy interpretacyjne". W Pro bono Reipublicae. Księga jubileuszowa prof. Michała Pietrzaka. 477486. Red. Paweł Borecki, Andrzej Czohara, Tadeusz Jacek Zieliński. Warszawa: LexisNexis.

Walencik, Dariusz. 2010. „Realizacja art. 25 ust. 5 Konstytucji RP”. Państwo i Prawo 6: 42-54.

Walencik, Dariusz. 2011. „Konsensualna regulacja stosunków między państwem a związkami wyznaniowymi w Rzeczypospolitej Polskiej”. W Kościól a polityka. 97-112. Red. Marcin Worbs. Opole: Redakcja Wydawnictw Wydziału Teologicznego Uniwersytetu Opolskiego.

Witkowski, Zbigniew. 2000. „Opinia w sprawie zagadnień prawnych wynikających z art. 25 ust. 5 Konstytucji RP”. Przeglad Legislacyjny 2(24): 97-107.

Zieliński, Tadeusz Jacek. 2003. „Regulacja stosunków między państwem a związkami wyznaniowymi w trybie art. 25 ust. 5 Konstytucji RP”. Państwo i Prawo 7: 48-54.

Zieliński, Tadeusz Jacek. 2009. „Niekompetencja religijna władz publicznych jako aspekt zasady bezstronności z art. 25 ust. 2 Konstytucji RP”. W Bezstronność religijna, światopogladowa i filozoficzna władz Rzeczypospolitej Polskiej. 141-167. Red. Tadeusz Jacek Zieliński. Warszawa: Chrześcijańska Akademia Teologiczna.

Zieliński, Tadeusz Jacek. 2017. „Asygnata podatkowa na związki wyznaniowe - uwagi o projekcie ustawy przygotowanym przez administrację rządową w 2013 r." Przegląd Prawa Wyznaniowego 9: 95-112.

\section{Łukasz Bernaciński}

\section{CONSIDERATIONS ON THE EQUALIZATION THE LEGAL POSITION OF CHURCHES AND OTHER RELIGIOUS ORGANIZATIONS AND NON-CONFESSIONAL ORGANIZATIONS}

\footnotetext{
Abstract. This chapter is an attempt to answer the question about the existence of premises supporting the obligatory equalization of the legal position of churches and other religious organizations and nonreligious ideological organizations. For this purpose has analyzed the legal
} 
status of entities, the attitude of the European Union to the discrepancies occurring in this field and the functions that the entities fulfill towards their members. Context for considerations are bills created in the years 2013-2019, concerning the replacement of the Church Fund tax write-off for churches and other religious organizations, and granting to nonreligious ideological organizations the right to a permanent, institutional dialogue with the state.

Keywords: equal rights, churches, religious organizations, non-confessional organizations. 